\title{
Ixodes kangdingensis (Acari: Ixodidae), a new species from the Siberian weasel, Mustela sibirica (Carnivora: Mustelidae) in China
}

\author{
TIANYU GUO ${ }^{1,2}$, YI SUN ${ }^{1}$, GUANG XU ${ }^{3}$ and LANCE A. DURDEN ${ }^{4}$ \\ ${ }^{1}$ State Key Laboratory of Pathogens and Biosecurity, Department of Vector Biology and Control, Beijing Institute of \\ Microbiology and Epidemiology, No. 20, Dongdajie Street, Fengtai District, Beijing City 100071, China \\ ${ }^{2}$ Institute of Health Inspection and Quarantine, Chinese Academy of Inspection and Quarantine, No 11.Ronghuananlu St., \\ Daxing Dis., Beijing City 1000176, China \\ ${ }^{3}$ Department of Microbiology, University of Massachusetts, Amherst, MA 01003, USA \\ ${ }^{4}$ Department of Biology, Georgia Southern University, 4324 Old Register Road, Statesboro, GA 30458, USA
}

(Received 21 fanuary 2017; revised 8 May 2017; accepted 9 May 2017)

\section{SUMMAR Y}

The female and nymph of Ixodes (Pholeoixodes) kangdingensis n. sp. are described based on both morphology and analysis of $16 \mathrm{~S}$ rRNA gene sequences. Specimens of this new tick species were collected from a Siberian weasel (Mustela sibirica) in Kangding County, Sichuan Province, China. The morphological features of the female and nymph are unique to distinguish I. kangdingensis $\mathrm{n}$. sp. from other members of the subgenus Pholeoixodes, including the presence of distinctly shaped cornua, anterior and posterior processes on palpal article I and a large angular projection on each side of the hypostome. Partial sequence of 16S rRNA gene grouped this species with Ixodes arboricola and Ixodes lividus with sequence divergence of new species from I. arboricola $4 \cdot 16 \%$ and from I. lividus $8 \cdot 49 \%$. Data on the phylogenetic position, hosts, geographic distribution and key to females of closely related species are also provided.

Key words: Pholeoixodes, Ixodes kangdingensis, new species, Ixodidae, China.

\section{INTRODUCTION}

Worldwide, the genus Ixodes Latreille, 1795 currently includes 244 recognized valid species (Barker and Murrell, 2008; Guglielmone et al. 2014), which are divided into 16 recognized subgenera (Clifford et al. 1973; Robbins and Keirans, 1992). The subgenus Pholeoixodes comprises $\sim 25$ valid species, and its members are mainly distributed in the Palearctic, Nearctic and Neotropical biogeographical regions (Robbins and Keirans, 1992). Members of this subgenus usually parasitize mammals and birds (Arthur, 1965; Emel'yanova, 1979) and some species have been implicated in the transmission of the aetiologic agents of Lyme disease, human anaplasmosis and spotted fever group rickettsioses (Damrow et al. 1989; Spitalska et al. 2011). In total 19 species in the subgenus have been adequately studied morphologically; however, the males of four species, the nymph of one species and the larvae of three species are still largely undescribed (Guglielmone and Nava, 2014). In China, 27 species of genus Ixodes

* Corresponding author: State Key Laboratory of Pathogens and Biosecurity, Department of Vector Biology and Control, Beijing Institute of Microbiology and Epidemiology, No.20, Dongdajie Street, Fengtai District, Beijing City 100071, China. E-mail: sunyi73@, gmail.com belonging to seven subgenera have been reported (Teng, 1986; Teng and Jiang, 1991; Chen et al. 2010; Guo et al. 2016), including three species, Ixodes arboricola Schulze and Schlottke, Ixodes crenulatus Koch and Ixodes myospalacis Teng, from the subgenus Pholeoixodes. In this paper, we describe a new species belonging to this subgenus Pholeoixodes collected from a Siberian weasel, Mustela sibirica Pallas in Sichuan, China. DNA sequences of the $16 \mathrm{~S}$ rRNA gene were used to further authenticate the validity of the new species and to associate nymphs with adult females.

\section{MATERIALS AND METHODS}

\section{Tick collection}

Females and nymphs of the new species were collected from a Siberian weasel. The weasel was caged at Kangding County $\left(30^{\circ} 03^{\prime} \mathrm{N}, 101^{\circ} 58^{\prime} \mathrm{E}\right)$ (online Supplementary Fig. S1) during a surveillance for small mammals in Sichuan Province, China, in 1986. Collection of weasels and rodents was authorized through the System of Authorization and Information on Biodiversity of China (361507). The weasel was examined on an enamel pan for ticks with fine tip tweezers after anaesthetized by ether. A total of 10 females and 12 nymphs were collected and no male or larva was retrieved in the following field surveys since then. 


\section{Morphological identification}

The tick specimens were examined, and micrographs were produced through light and scanning electron microscopy (Hitachi S-3400N, Hitachi, Japan) in the Electron Microscopy Laboratory, in Beijing Institute of Microbiology and Epidemiology, State Key Laboratory of Pathogen and Biosecurity of China. Females and nymphs of the new species were examined under both high and low vacuum, respectively. For comparison with the morphologically similar species, I. myospalacis (holy type, female, IOZ9084571; paratype, nymph, IOZ9084572), deposited in the Institute of Zoology, Chinese Academy of Science, Beijing and Ixodes texanus Banks (paratype, female, RML065923), deposited in the Museum Support Center, Smithsonian Institution, Washington, DC 20560, USA(currently at Georgia Southern University, Statesboro, Georgia, USA), were also examined under light microscopes. All reported measurements are in millimetres $(\mathrm{mm})$; ranges are listed first, followed by means and sample sizes.

\section{Molecular procedures}

After morphological identification, two females and four nymphs were sampled from their groups with definitely diagnostic characteristics and submitted to screen molecularly. Briefly, genomic DNA was extracted from two females and four nymphs using Black PREP Tick DNA kits (Life science, Darmstadt, Germany) and standard polymerase chain reaction was performed targeting mitochondrial $16 \mathrm{~S}$ rRNA gene using primer set $16 \mathrm{~S}+1$ and 16S-1 (Black and Piesman, 1994). A 460 base pairs long mitochondrial $16 \mathrm{~S}$ rRNA gene fragment was purified and sequenced using the aforementioned primer set. Multiple sequence alignments were conducted with Clustal X (Thompson et al. 1997). Phylogenetic trees were reconstructed using maximum parsimony (MP) methods as implemented in MEGA 6.0 (Tamura et al. 2013) with 1000 replicates of random addition and tree bisection and reconnection using a branch swapping algorithm. Ixodes trianguliceps Birula was used as an outgroup because the species is the most completely studied representative of subgenus Exopalpiger, which is close to subgenus Pholeoixodes in taxonomic and phylogeny and possesses distinct differential morphological characters (Clifford et al. 1973; Heylen et al. 2014).

\section{RESULTS}

\section{Description of Ixodes (Pholeoixodes) kangdingensis} n. $s p$.

Diagnosis: Female: cornua subtriangular and prominent; auriculae as lateral salience or ridges; anterior and posterior processes on palpal article I; a large angular projection on each side of the hypostome on the ventral basis capituli. Scutum heart-shaped with conspicuous deep punctations near scapular areas and posterior margin; lateral carinae absent; anal grooves parallel.

Nymph: Basis capituli dorsally subtriangular, with distinct cornuae; auriculae as lateral saliences or ridges; anterior and posterior processes on palpal article I; a large angular projection on each side of the hypostome on the ventral basis capituli. Scutum suboval with shallow cervical groove; lateral carinae absent.

Holotype. Female: description based on a very slightly fed holotype and five slightly fed paratypes (Fig. 1).

Idiosoma (Fig. 1A): yellowish to brown coloured, oval, length from scapular apices to posterior body margin $2 \cdot 52-2 \cdot 55(2 \cdot 53 ; n=5)$, maximum width $1 \cdot 59-1 \cdot 61(1 \cdot 60 ; n=5)$, ratio length to width $1 \cdot 56$ $1 \cdot 57(1 \cdot 56 ; n=5)$. Marginal grooves completed and well delineated, gradually converging anteriorly and rounded posteriorly.

Scutum (Fig. 1B): outline heart shaped with slight emargination and blunt scapulae, the margins diverging in anterior one-third of total length, thereafter gradually converging to narrowly rounded posterior margin; length $1 \cdot 11-1 \cdot 13(1 \cdot 12 ; n=5)$, width $0 \cdot 98$ $0.99(0 \cdot 98 ; n=5)$, ratio length to width $1 \cdot 19-1 \cdot 20$ $(1 \cdot 19 ; n=5)$. Lateral carinae absent; cervical pit deep; cervical grooves shallow, parallel anteriorly, then diverging posteriorly along two-third of total length. The scutual punctations in posteromedian area are small and sparse, whereas in scapular areas and posterior margin, moderately sized and dense. Setae sparse, slender and shorter than those on alloscutum.

Alloscutum (Fig. 1A): with yellowish dorsal surfaces, length $1 \cdot 42-1 \cdot 44(1 \cdot 43 ; n=5)$; numerous setae, evenly distributed, length $0.068-0.070$ $(0 \cdot 069 ; n=5)$.

Venter (Fig. 1C): setae numerous, mainly distributed on posterior surface. Genital aperture (Fig. 1D) at level of coxae III, U-shaped; preatrial fold concave. Deep genital groove, subparallel anteriorly, divergent posteriorly, extending to margin.

Anal groove (Fig. 1E) horseshoe-shaped, anterior to anus, arms parallel-sided reaching posterior margin of idiosoma. Anal valves crescent with three pairs of tiny setae. Spiracular plate (Fig. 1F): oval, submarginal row of perforations complete, $\sim 7$ rows of large goblets, macula almost central and positioned on ventral surface in partially fed specimens. The longest diameter $0 \cdot 115-0 \cdot 117(0 \cdot 116$; $n=5)$, the shortest diameter $0 \cdot 078-0.080(0 \cdot 079$; $n=5)$, ratio length to width $1 \cdot 49-1 \cdot 52(1 \cdot 50 ; n=5)$.

Capitulum (Fig. 1G): length from palpal apices to posterior margin of basis capituli dorsally 

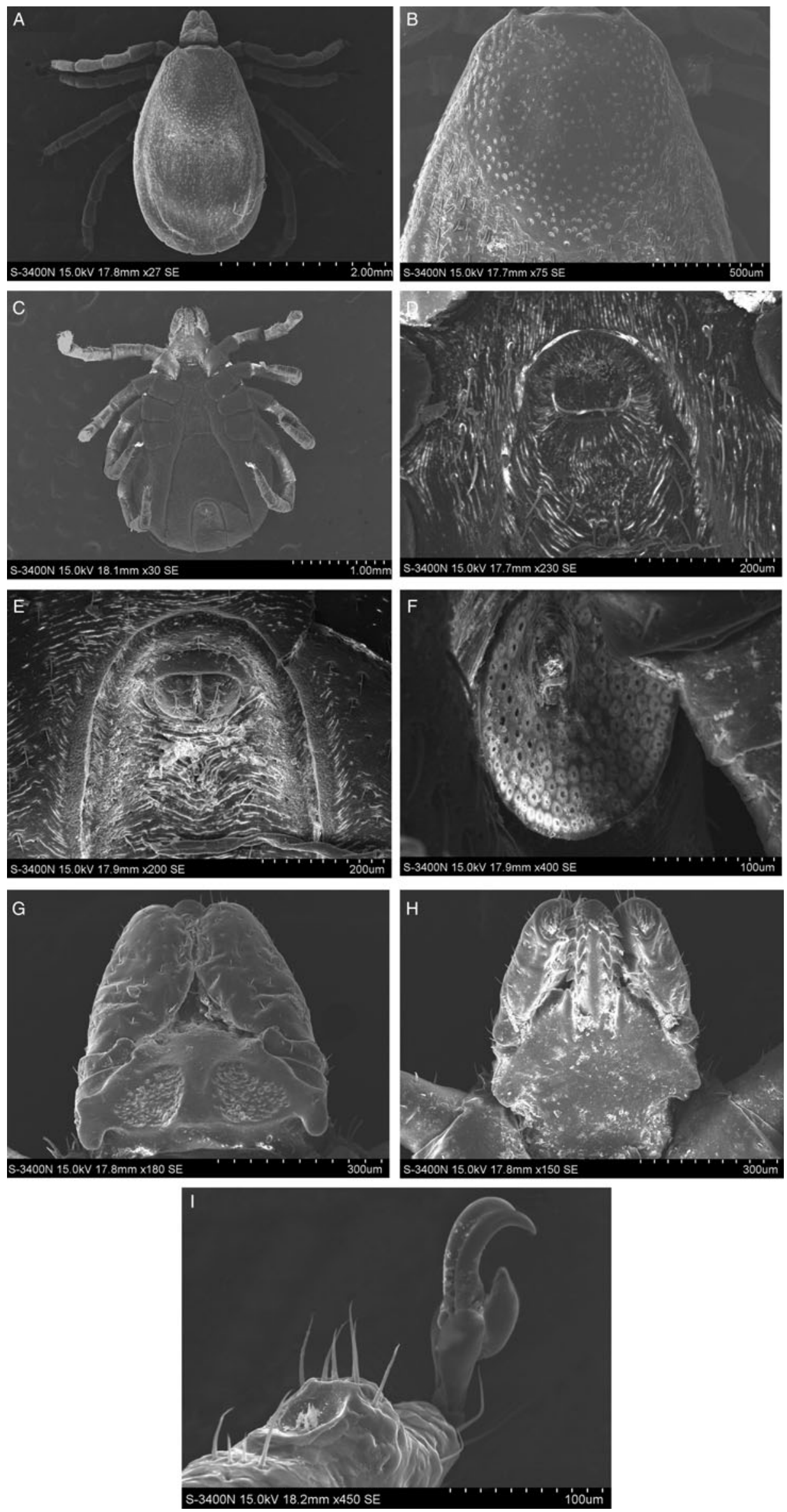

Fig. 1. Ixodes kangdingensis n. sp.(adult female, holotype): (A) dorsal view, entire; (B) scutum; (C) ventral view, entire;

(D) genital aperture; (E) anus; (F) spiracular plate; (G) basis capituli, dorsal view; cornuae and spurs on palpal article I are peculiar; (H) basis capituli, ventral view; angular projection on each hypostomal shoulder is peculiar; (I) tarsus I and pulvillus, ventral view. 
$0 \cdot 395-0 \cdot 408(0 \cdot 40 ; n=5)$, width at level of auriculae $0 \cdot 45-0 \cdot 47(0 \cdot 46 ; n=5)$, ratio length to width $1 \cdot 14$ $1 \cdot 16(1 \cdot 15 ; n=5)$

Basis capituli: dorsally subtriangular; lateral margins diverging slightly; posterior margin between cornuae straight. Porose areas subtriangular, inwardly inclined, deeply sunken with clearly circumscribed borders, separated by shallow depression, narrower than half of the width of porose area. Cornua triangular, longer than wide, with blunt apex. Basis capituli ventrally subrectangular with slightly convex posterior margin, with large angular projection on anterior margin of basis capituli on either side of hypostome. Auriculae, distinctive, prolonged posterolaterally. Transverse suture absent (Fig. 1H).

Palpi: club-like, short and broad; length (articles I-III) $0 \cdot 316-0 \cdot 319(0 \cdot 318 ; n=5)$, width $0 \cdot 105-$ $0 \cdot 107(0 \cdot 106 ; n=5)$, ratio length to width $2 \cdot 95$ $3 \cdot 10(3 \cdot 00 ; n=5)$, longest articles in descending order: $2,3,1,4$. Article I with two triangular processes, blunt but prominent, the anterior processes large and the posterior one small; articles II-IV lacking spurs or projections; article II narrow at base and thereafter parallel-sided; article III laterally straight and converging to bluntly rounded apex. Article IV situated in pit of apices of segment III.

Hypostome: parallel-sided with rounded apex; length from the level of post-hypostomal setae to its apex $0 \cdot 287-0 \cdot 290(0 \cdot 288 ; n=5)$, width $0 \cdot 134$ $0 \cdot 138(0 \cdot 135 ; n=5)$, ratio length to width $2 \cdot 12$ $2 \cdot 13(2 \cdot 13 ; n=5)$, not situated on median extension of basis capituli. Dental formula distally $3 \mid 3$, then $2 \mid 2$ to base, eight denticles in external and median files, three denticles in internal file, numerous tiny denticles in corona. Legs: moderately long, robust.

Coxae (Fig. 1C): coxa I with triangular internal spur with pointed apex, external spur absent; coxae II-IV each with sclerotized posterior margin; coxa II with rounded internal spur and no external spur; coxae III and IV each with indistinct external spur and no internal spur. Coxal setae shorter than the setae on sternal and ventral plates. Trochanters lacking spurs. Tarsi (Fig. 1I) narrowing abruptly subapically, especially tarsus I. Tarsus I length $0 \cdot 255-0 \cdot 261 \quad(0 \cdot 260 ; \quad n=5)$, width $0 \cdot 109-0 \cdot 111$ $(0 \cdot 110 ; n=5)$, ratio length to width $2 \cdot 35-2 \cdot 37$ $(2 \cdot 36 ; n=5)$; tarsus IV length $0 \cdot 148-0 \cdot 150(0 \cdot 149$; $n=5)$, width $0 \cdot 085-0 \cdot 087 \quad(0 \cdot 086 ; n=5)$, ratio length to width $1 \cdot 70-1 \cdot 75(1 \cdot 73 ; n=5)$.

Pulvilli (Fig. 1 I) very short, $\sim 2 / 3$ as long as claws.

Paratypes. Nymph: description based on five very slightly fed nymphs(Fig. 2):

Idiosoma (Fig. 2A): yellowish to brown coloured, suboval, widest between level of coxae III and IV, gradually narrowing posteriorly to level of spiracular plates, length $0 \cdot 716-0 \cdot 718(0 \cdot 717 ; n=5)$, maximum width $0.553-0.555(0.554 ; n=5)$, ratio length to width $1 \cdot 29-1 \cdot 31(1 \cdot 30 ; n=5)$. Marginal grooves completed and well delineated, gradually converging anteriorly and rounded posteriorly.

Scutum (Fig. 2B): length 0.429-0.430 (0.429; $n=$ $5)$, width $0 \cdot 420-0 \cdot 421(0 \cdot 420 ; n=5)$, ratio length to width $1.00-1.02(1 \cdot 01 ; n=5)$; suboval, posterior margin broadly rounded, lateral fields with shallow depressions. Emargination deep; lateral carinae faint. Cervical grooves distinct, deep, converging, then diverging to near posterior margin of scutum. Scapular angles blunt. Scutal surface smooth with few, indistinct, punctations. Setae $\sim 9-10$ pairs, length $0.033-0.037(0.036 ; n=5)$, approximately one-third as long as alloscutumal ones.

Alloscutum (Fig. 2A): dorsal setae numerous, evenly distributed, length 0.075-0.078 (0.076; $n=10)$.

Venter (Fig. 2D): setae numerous; distinct anterior anal groove with arms parallel-sided reaching posterior margin of body, anal valves with three pairs of associated setae. Spiracular plate (Fig. 2C): oval, $\sim 3$ rows of large goblets, maximum length in dorsoventral plane, length 0.087-0.0.089 (0.088; $n=5)$, width $0.058-0.060 \quad(0.059 ; n=5)$, ratio length to width $1 \cdot 49-1 \cdot 51 \quad(1 \cdot 50 ; n=5)$; macula almost central.

Capitulum (Fig. 2E): length from hypostomal apex to posterior dorsal margin of basis capituli1.33-1.35 $(1 \cdot 34 ; \quad n=5)$, width $0 \cdot 315-0 \cdot 318$ $(0 \cdot 316 ; n=5)$; ratio length to width $0 \cdot 882-0 \cdot 0 \cdot 885$ $(0 \cdot 883 ; n=5)$.

Basis capituli (Fig. 2F): dorsally subtriangular, short and broad with a prominent subtriangular cornuae, pointed and posterolateral directed. Basis capituli ventrally suboval with slightly convex posterior margin, with large angular projection on anterior margin of basis capituli on either side of hypostome; auriculae, blunt triangular, directed posteriorly, transverse suture absent.

Palpi (Fig. 2E): club-like, length $0 \cdot 217-0 \cdot 221$ $(0 \cdot 219 ; n=5)$, width $0 \cdot 108-0 \cdot 111(0 \cdot 109 ; n=5)$, ratio length to width $1 \cdot 98-2 \cdot 05 \quad(2 \cdot 00 ; n=5)$. Article I well developed, cylindrical with two triangular processes, one dorsal and the other one ventral. Distinct suture present between articles II and III, one ventral seta present. Article II longest, narrow proximally, expanding distally with five dorsal and three ventral setae. Article III broad proximally, narrowing distally with one ventral and 4-5 dorsal setae. Article IV flexible with $\sim 16$ setae. Hypostome (Fig. 2F): length from apex to the level of post-hypostomal setae $0 \cdot 143$ $0 \cdot 145(0 \cdot 144 ; n=5)$, width at the middle length $0.054-0.056(0.055 ; n=5)$, ratio length to width $2 \cdot 65-2 \cdot 68(2 \cdot 67 ; n=5)$; parallel-sided with rounded apex, protruding anteriorly well beyond palpal apices. Dental formula $2 \mid 2$, six denticles in each file. One pair of post-hypostomal setae present.

Legs (Fig. 2D): moderately elongate, robust. 

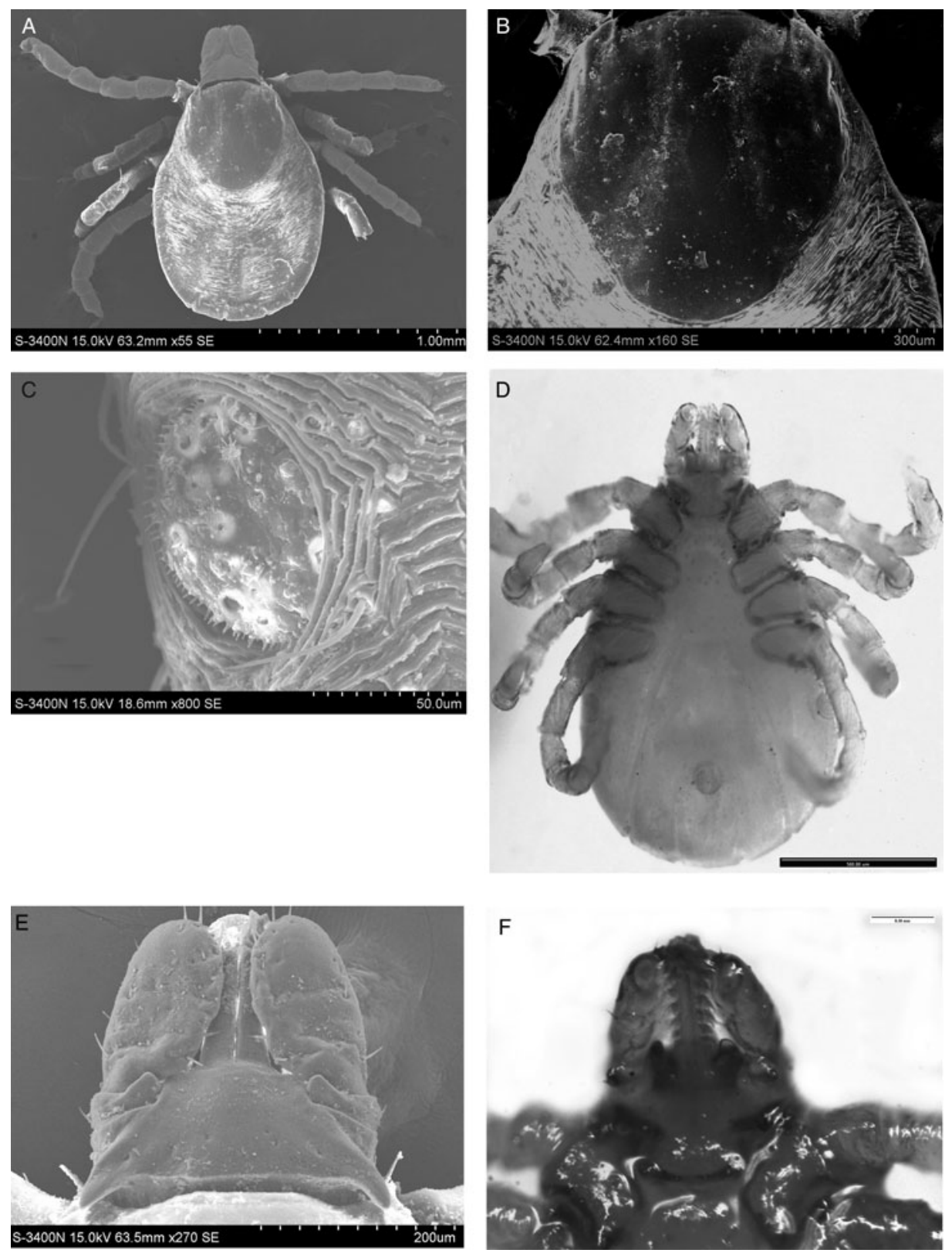

Fig. 2. Ixodes kangdingensis n. sp.(nymph, paratype): (A) dorsal view, entire; (B) scutum; (C) spiracular plate; (D) ventral view, entire; (E) basis capituli, dorsal view; cornuae and spurs on palpal article I are peculiar; (F) basis capituli, ventral view. Angular projection on each hypostomal shoulder and spurs on palpal article I are peculiar.

Coxae (Fig. 2D): coxa I with small internal spur, triangular, blunt, no external spur; Coxae II-IV with narrow sclerotized posterior margins, each with slight indication of internal spur, external spur virtually absent. Three setae on each coxa. Trochanters lacking spurs. Tarsi abruptly narrowed subapically, especially tarsus I. Tarsus I length $0 \cdot 240-0 \cdot 243 \quad(0 \cdot 241 ; n=5)$. Tarsus IV length $0 \cdot 135-0 \cdot 137(0 \cdot 135 ; n=5)$.

\section{Molecular observations}

The sequences from adults and nymphs were identical when aligned using Clustal $\mathrm{X}$ and were deposited in the GenBank under accession no. KT825683. This finding of genetic identity confirms and conforms to the spatial and temporal association between nymphs and adult females of I. kangdingensis on the same host animal. Phylogenetic relationships based on a 412 base pairs segment of the mitochondrial 16S rRNA gene (Fig. 3) grouped $I$. kangdingensis $\mathrm{n}$. sp. with I. arboricola and I. lividus within a strongly supported branch $(75 \%$ bootstrap and 0.80 posterior probability). The sequence divergence between $I$. kangdingensis $\mathrm{n}$. sp. and I. arboricola was $4 \cdot 16 \%$ and between $I$. kangdingensis $\mathrm{n}$. sp. and I. lividus, $8 \cdot 49 \%$.

\section{Taxonomic summary}

Holotype: female, ex Siberian weasel (M. sibirica Pallas) (Mammalia: Carnivora: Mustelidae), China: 


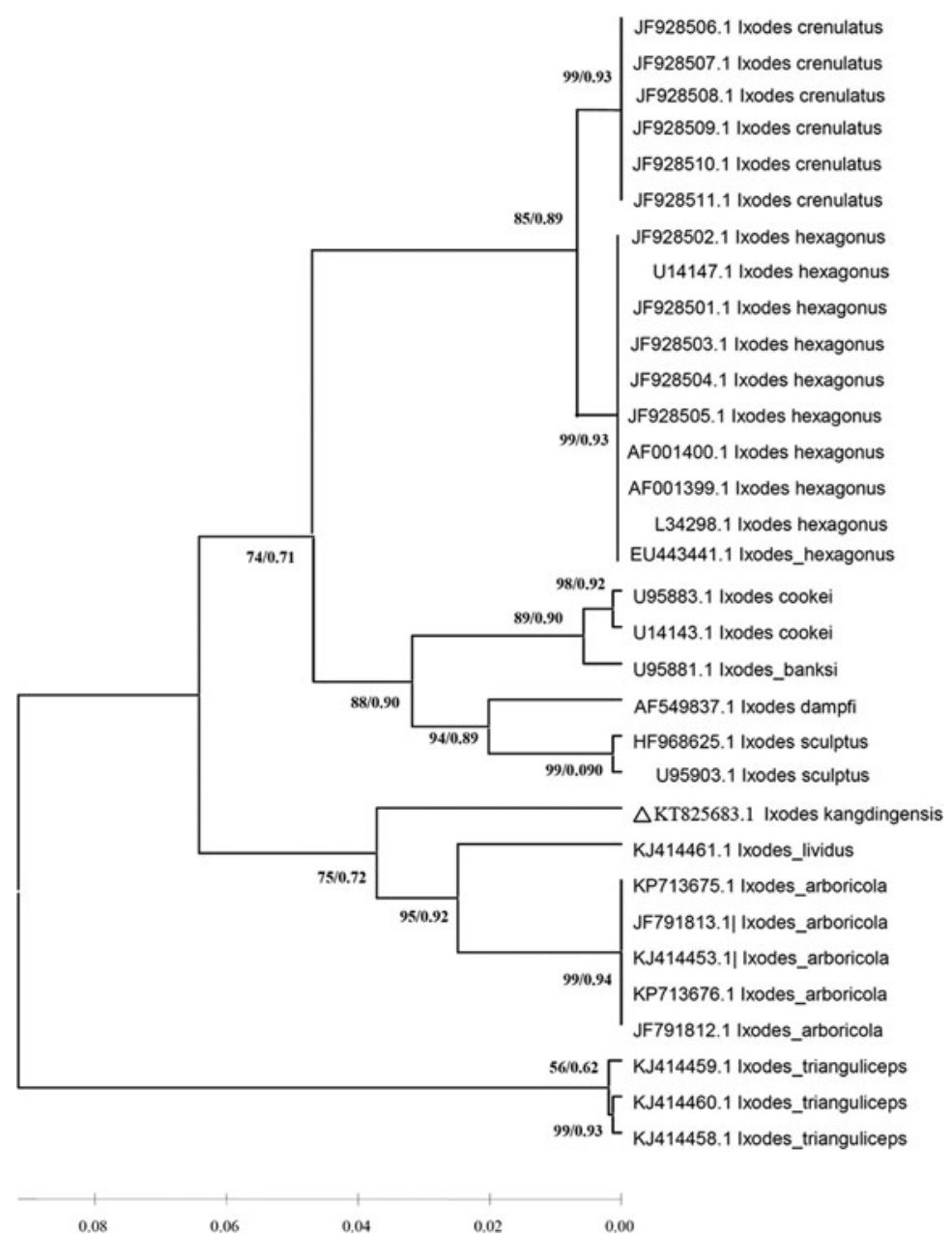

Fig. 3. Phylogenetic tree including Ixodes kangdingensis and other selected species of Ixodes based on 16S rDNA. The alignment was produced using Clustal $\mathrm{X}$ and the tree was inferred by means of the MP method with 500 replicates of random addition. Ixodes trianguliceps was used as an outgroup. The Bayesian support (posterior probability) values are derived from 1000000 replicates.

Sichuan Province, Kangding County, Kangding $\left(30^{\circ} 03^{\prime} \mathrm{N}, 101^{\circ} 58^{\prime} \mathrm{E}\right)$, July 15,1986 , collected by T. Y. Guo, deposited in the Medical Entomology Gallery of the Academy of Military Medical Sciences, Beijing, China (AMMSC) (accession no. AMMSC-T-10349).

Paratypes: five females, six nymphs, same collection data as holotype, deposited in the AMMSC (accession no. AMMSC-T-10350).

Distribution and hosts: Siberian weasel is the only host of I. kangdingensis n. sp. up to now. Since weasels inhabit terrestrial and aquatic regions throughout the world except in Australia, Antarctica and most oceanic islands, the new species may not be confined to Sichuan Province, China.

Etymology: the name of the species is derived from the collection site.

\section{DISCUSSION}

Generally, I. kangdingensis $\mathrm{n}$. sp. described in the present paper possesses distinct morphological characters, which assigns the novel species to the subgenus Pholeoixodes. The combination of following characters listed as (1) article I of palpi is distinctive, in that it is not fused with, or embedded in the basis capituli, and distinct spurs are present on this palpal article I; the auriculae are at most as slight elevations. (2) The hypostome is rounded anteriorly and widest at its midlength, and it is not borne on a median extension of the basis capituli; (3) coxae without membranous outgrowths (syncoxae) and coxae I-II lack external spur; no spur on trochanters; (4) no apron around the genital aperture and anal groove may be faint (Kleinjan and Lane, 2008). However, the presence of blunt triangular processes on palpal article I and the large angular projection on the anterior margin of the basis capituli on either side of hypostome, as well as the distinct long cornuae, are the main characters that morphologically distinguish the female of $I$. kangdingensis $\mathrm{n}$. $\mathrm{sp}$. from other species belonging to the subgenus Pholeoixides. Briefly, the basis capituli lacks cornua in the female of $I$. cremulatus, $I$. arboricola, Ixodes kaiseri Arthur, I. lividus, Ixodes baergi 
Cooley and Kohls and Ixodes banksi Bishopp, which can separate I. kangdingensis $\mathrm{n}$. sp. from these six species. Although, I. myospalacis (re-examined holotype IOZ9084571) and Ixodes subterraneus Filippova possess rounded corners or small-rounded cornuae on basis capituli, the corners or the cornuae are so faintly formed that can distinctively distinguish the two species from $I$. kangdingensis n. sp., whose cornuae are prominent triangular, directed posterolaterally, with its length greater than the width at base. Furthermore I. myospalacis has a distinct transverse suture on the ventral basis capituli and faint lateral carinae on scutum whereas I. kangdingensis $\mathrm{n}$. sp. lacks such structures. And the distinct lateral carinae on the scutum of $I$. subterraneus can make it easy to distinguish these species. Moreover, I. kangdingensis n. sp. also resembles $I$. texanus, the female and male of which are recognized by rugose surfaces on the dorsal capitulum and scutum; relative small protruding lateral humps on the anterior margin of the basis capituli on either side of hypostome (Keirans and Clifford, 1978; Sonenshine, 1979). However, the prominent processes on palpal article I in the female of I. kangdingensis $\mathrm{n}$. sp. can separate it from the female of I. texanus. When compared with female Ixodes caledonicus Nuttall, which possess wide cornuae on the posterior margin of basis capituli and sharp external spur on coxa I, I. kangdingensis $\mathrm{n}$. sp. has cornuae much longer and no external spur on coxa I (online Supplementary Fig. S2). Unfortunately, no male or larva of $I$. kangdingensis $\mathrm{n}$. sp. has been recovered and no alternative measure to obtain them under laboratory conditions, which makes thorough comparisons of these species in this subgenus difficult.

Distinct morphological characters of the nymph of $I$. kangdingensis $\mathrm{n}$. sp. also represents as the presence of an angular projection on the anterior margin of the basis capituli on either side of the hypostome, blunt triangular processes on palpal article I and distinctly shaped cornuae. The new species is phylogenetically related to the morphologically distinct I. arboricola and I. crenulatus, which occurs in the Afrotropical, Oriental and Palearctic regions, and parasitizes birds. However, the nymphs of $I$. arboricola and $I$. crenulatus can easily be distinguished from that of $I$. kangdingensis because the former two species lack cornua on basis capituli and angular projections on the anterior margin of either side of the hypostome on basis capituli. In addition, the nymph of $I$. myospalacis also resembles the nymph of I. kangdingensis; however, the former possesses distinct lateral carinae on scutum and three setae on each anal valve, whereas in the nymph of I. kangdingensis, no lateral carinae on scutum and only two pairs of setae on anal valves were observed.

Weasels inhabit terrestrial and aquatic regions throughout the world except Australia, Antarctica and most oceanic islands, and serve as hosts for some Pholeoixodes species, for instance, I. hexagonus and Ixodes rugicollis in Mustela putorius (Feider, 1965) and I. gregsoni, I. texanus in Mustela vison and Mustela frenata (Whitaker and Goff, 1979; Lindquist et al. 1999). Due to the diverse habitats of the host weasels, the new species I. kangdingensis n. sp. might have wider geographic distribution than currently realized. However, little is known about the ecological characters of I. kangdingensis n. sp. or about the medical and veterinary importance.

\section{Key to species closely related to I. kangdingensis in} subgenus Pholeoixodes in Euroasia

Only a key to the females was provided for the underdescribed males of Ixodes mysopalacis and $I$. kangdingensis in the group.

1. Basis capituli without cornua; palpi II as long as III with indistinct boundary; coxa I without internal spur........................................ 2 Basis capituli with cornuae; palpi II longer than III with distinct boundary; coxa I with internal spur................................................... 6

2. Tip of hypostome rounded ..................... 3 Tip of hypostome slightly indented or flattened

3. Coxa I with rudimentary external spur. Auriculae faintly formed at best as slight elevations. Hypostomal dentition from apex to base $3 \mid 3$ to $2 \mid 2$, scutum hexagonal, tarsi humped apically .................................... hexagonus Coxa I without internal and external spurs, posterointernal angle of coxa I bluntly angled, tarsus humped apically ..............................canisuga

4. Area adjacent to cervical grooves on scutum characterized by strong longitudinal undulations which at or just behind mid-length become irregularly arranged ........................... lividus Posterointernal angle of coxa I broadly angled

5. Lateral carina on scutum distinct. Porose areas deep, with sclerotized ridge on inner margin ....................................... crenulatus Lateral carina on scutum indistinct. Porose areas separated by a depression with no ridge on inner margins.......................................arboricola

6. Cornua on basis capituli indistinctive, faint and short; no projection on hypostomal shoulders

Cornuae on basis capituli distinct ................ 8

7. Palpal segment III with three times long as wide; scutum heart-shaped with indistinct lateral carina ......................................myospalacis Palpal segment III with two times long as wide; scutum oval with distinct lateral carina

subterraneus 
8. Cornuae, triangular, the length greater than the width, external spur on coxa I absent; angular projection represents on each side of hypostomal shoulders kangdingensis $\mathrm{n} . \mathrm{sp}$. Cornuae wide triangular, the width greater than the length, external spur represents as triangular and sharp, palpi strongly concave on outer margins. Hypostomal dentition $2 \mid 2$ for almost the entire length..... caledonicus

\section{SUPPLEMENTARY MATERIAL}

The supplementary material for this article can be found at https://doi.org/10.1017/pao.2017.7.

\section{ACKNOWLEDGEMENTS}

The authors are grateful to Chen Jun, IZCAS, to Richard G. Robbins and James E. Keirans, formerly at the Museum Support Center, Smithsonian Institution, Washington, DC, USA for providing access to type specimens, and to Karen McCoy (French National Centre for Scientific Research, Paris) for constructive advice on the manuscript. This study was supported by the Ministry of Science and Technology of China (Grant No. 2006FY120100), the National Science Foundation of China (Grant No. 30400364 and 30872196) and the National Critical Project for Science and Technology on Infectious Disease of P. R. China (Grant No. 2012ZX10004219).

\section{REFERENCES}

Arthur, D. R. (1965). Ticks of the Genus Ixodes in Africa. Athlone Press, London, UK, $348 \mathrm{p}$

Barker, S. C. and Murrell, A. (2008). Systematics and evolution of ticks with a list of valid genus and species names. In Ticks: Biology, Disease and Control (eds. Bowman, A. S. and Nuttall, P. A.), pp. 1-39. Cambridge University, Cambridge, UK

Black, W. C., IV and Piesman, J. (1994). Phylogeny of hard- and soft-tick taxa (Acari: Ixodida) based on mitochondrial 16S rDNA sequences. Proceedings of the National Academy of Sciences of the USA 91, 10034-10038. Chen, Z., Yang, X., Bu, F., Yang, X., Yang, X. Y. and Liu, J. Z. (2010). Ticks (Acari: Ixodoidea: Argasidae, Ixodidae) of China. Experimental छ Applied Acarology 51, 393-404.

Clifford, C. M., Sonenshine, D. E., Keirans, J. E. and Kohls, G. M. (1973). Systematics of the subfamily Ixodinae (Acarina: Ixodidae). I. The subgenera of Ixodes. Annals of the Entomological Society of America 66, 489-500. Damrow, T., Freedman, H., Lane, R. S. and Preston, K. L. (1989). Is Ixodes (Ixodiopsis) angustus a vector of Lyme disease in Washington State? Western Fournal of Medicine 150, 580-582.
Emel'yanova, N. D. (1979). Taxonomic status of ixodid ticks of the genus Pholeoixodes within the subfamily Ixodinae and its division into subgenera. In Zooparasitology of Lake Baikal Basin (eds. Efimov, M. V and N. M. Pronin), pp. 5-27. Akademy Nauk SSSR, Siberyan Otdelenie Buryatia, Filial, Otdelenie Biology, Ulan-Ude, Siberia.

Feider, Z. (1965). Acaromorpha, Suprafamily Ixodoidea. In Fauna of the Popular Republic of Romania (ed. Feider, Z.), 401p. Editura Academiei Republicii Populare Române, Bucharest.

Guglielmone, A. A. and Nava, S. (2014). Names for Ixodidae (Acari: Ixodoidea): valid, synonyms, incertaesedis, nominadubia, nominanuda, lapsus, incorrect and suppressed names-with notes on confusions and misidentifications. Zootaxa 3767, 1-256.

Guglielmone, A. A., Robbins, R. G., Apanaskevich, D. A., Petney, T. N., Estrada-Peña, A. and Horak, I. G. (2014). Part I The Genus Ixodes. In The Hard Ticks of the World (Acari: Ixodida: Ixodidae), pp. 10-216. Springer, Dordrecht.

Guo, Y., Sun, Y. and Xu, R. M. (2016). The genus Ixodes (Acari: Ixodidae) in China with three new record species. Acta Parasitologica 61 729-742.

Heylen, D., Coninck, E. D., Jansen, F. and Madder, M. (2014). Differential diagnosis of three common Ixodes spp. ticks infesting songbirds of Western Europe: Ixodes arboricola, I. frontalis and I. ricinus. Ticks and Tick-borne Diseases 5, 693-700.

Kleinjan, J. E. and Lane, R. S. (2008). Larval keys to the genera of Ixodidae (Acari) and species of Ixodes (Latreille) ticks established in California. Pan-Pacific Entomology 84, 121-142.

Keirans, J. E. and Clifford, C. M. (1978). The genus Ixodes in the United States: a scanning electron microscope study and key to the adults. Fournal of Medical Entomology 2, 1-149.

Lindquist, E. E., Wu, K. W. and Redner, J. H. (1999). A new species of the tick genus Ixodes (Acari: Ixodidae) parasitic on mustelids (Mammalia: Carnivora) in Canada. Canadian Entomologist 131, 151-170.

Robbins, R. G. and Keirans, J. E. (1992). Systematics and ecology of the subgenus Ixodiopsis (Acari: Ixodidae: Ixodes). In Thomas Say Publ. Entomology Monographs, Entomological Society of America (ed. Robbins, R. G. and Keirans, J. E.), 159p. Lanham, Maryland. Sonenshine, D. E. (1979). Ticks of Virginia (Acari: Metastigma). In Insects of Virginia No. 13 (ed. Sonenshine, D. E.), pp. 1-44. Virginia Polytechnic Institute and State University Blacksburg, Virginia. Spitalska, E., Literak, I., Kocianova, E. and Taragelova, V. (2011) The Importance of Ixodes arboricola in Transmission of Rickettsia spp. Anaplasma phagocytophilum, and Borrelia burgdorferi sensu lato in the Czech Republic, Central Europe. Vector-Borne and Zoonotic Diseases 11, 1235-1241.

Tamura, K., Stecher, G., Peterson, D., Filipski, A. and Kumar, S. (2013). MEGA6: Molecular Evolutionary Genetics Analysis version 6·0. Molecular Biology and Evolution 30, 1-5.

Teng, K. F. (1986). Studies of the genus Ixodes in China. Acta Zootaxonomic Sinica 11, 46-53.

Teng, K. F. and Jiang, Z. J. (1991). Fasc 39. Acarina: Ixodidae. In Economic Insect Fauna of China (ed. Teng, K. F. and Jiang, Z. J.), Academia Sinica, Beijing, 359p.

Thompson, J. D., Gibson, T. J., Plewniak, F., Jeanmougin, F. and Higgins, D. G. (1997). The CLUSTAL X windows interface: flexible strategies for multiple sequence alignment aided by quality analysis tools. Nucleic Acids Research 25, 4876-4882.

Whitaker, J. O. and Goff, R. (1979). Ectoparasites of wild carnivora of Indiana. Fournal of Medical Entomology 15, 425-430. 